\title{
PENGARUH DISPLAY, PROMOSI PENJUALAN DAN KUALITAS PRODUK PADA TOKO ONLINE TERHADAP LOYALITAS KONSUMEN DENGAN VARIABEL INTERVENING KEPUASAN PELANGGAN
}

\author{
Heni Iswati ${ }^{1}$, Novia Indah Lestari ${ }^{2}$ \\ Universitas Budi Luhur, Jakarta ${ }^{1}$ \\ Jl. Ciledug Raya No.99, RW.3, Petukangan Utara, Kec. Pesanggrahan, Kota Jakarta \\ Selatan, Daerah Khusus Ibukota Jakarta 12260 \\ Universitas Serang Raya, Serang ${ }^{2}$ \\ Jl. Raya Cilegon No.Km. 5, Taman, Drangong, Kec. Taktakan, Kota Serang, Banten 42162 \\ Email: heni.iswati@gmail.com ${ }^{1}$, noviaindahl@unsera.ac.id ${ }^{2}$
}

\begin{abstract}
ABSTRAK
Perkembangan teknologi mendorong perilaku belanja konsumen bergeser ke arah digital. Dengan beralihnya perilaku konsumen pada sikap belanja online, mendorong produsen untuk mampu bersaing dalam mempertahankan usahanya. Tujuan dari penelitian ini adalah untuk mengetahui pengaruh display, promosi penjualan, dan kualitas produkyang dijual secara online terhadap loyalitas konsumen dengan menambahkan variabel intervening kepuasan pelanggan untuk melihat pengaruhnya. Sampel yang digunakan dalam penelitian ini sebanyak116 responden di Kota Bandung yang pernah melakukan pembelian produk secara online.Hasil penelitian menunjukkan display toko online secara parsial tidak berpengaruh dan signifikan terhadap loyalitas konsumen, sedangkan promosi penjualan dan kualitas produk berpengaruh dan signifikan terhadap loyalitas konsumen. Secara Simultan display dan promosi penjualan tidak signifikan terhadap loyalitas konsumen dan berdasarkan hasil perhitungan promosi penjualan dan kualitas produk berpengaruh terhadap loyalitas konsumen. Hasil perhitungan setelah ditambahkan intervening, kepuasan pelanggan dengan sobel test, berpengaruh mediasi karena konsumen yang puas dengan kualitas produk mampu meningkatkan loyalitas konsumen. Display dan promosi penjualan, setelah dimasukkan variabel intervening tidak mampu meningkatkan loyalitas konsumen karena kepuasan pelanggan atas display toko online dan promosi rendah. Dari hasil penelitian tersebut diharapkan para pengusaha toko online selain memperhatikan kualitas pada produk juga harus memperhatikan tampilan atau display pada website mereka dan juga harus melakukan promosi penjualan di berbagai media social selain website.
\end{abstract}

Kata Kunci : Display, promosi penjualan, kualitas produk, kepuasan pelanggan, loyalitas konsumen.

\section{ABSTRACK}

Technological developments are driving consumer spending behavior to shift toward digital. By shifting consumer behavior to online shopping attitudes, encouraging producers to be able to compete in maintaining their business. The purpose of this study was to determine the effect of online store displays, sales promotions, and quality of products on consumer loyalty by adding intervening variables customer satisfaction to see their effects. 116 Respondents in Bandung City who have purchased online product. The 
results showed displays store online that partially has no effect and significant on customer loyalty, while sales promotions and product quality had a significant effect on customer loyalty. Simultaneously the display and sales promotion are not significant on consumer loyalty and based on the results of the calculation of sales promotions and product quality affect customer loyalty. The results of the calculation after adding intervening, customer satisfaction with a Sobel test, has a mediating effect because consumers who are satisfied with product quality can increase consumer loyalty. Display and sales promotion, after entering the variable is intervening not able to increase customer loyalty because of customer satisfaction with displays store online and low promotions. From the results of this study, for the online store entrepreneurs, beside their concern to the product quality their must concern to the display on websites and also have to carry out sales promotions on various social media besides the website.

Keyword : Online store, display, sales promotion, quality product, customer satisfaction, customer loyalty

\section{PENDAHULUAN}

Website merupakan salah satu media yang dimiliki oleh pembisnis untuk menyampaikan informasi atas produk dan jasanya. Hampir semua perusahaan bisnis sekarang mempunyai website, yang pada beberapa tahun yang lalu dianggap sebagai sesuatu yang tidak mungkin dilaksanakan. Namun saat ini, apapun yang akan dilakukan perusahaan, lembaga, organisasi maupun individu untuk menyampaikan informasi, melakukan negosiasi maupun kesepakatan bisnis, dapat dilakukan melalui internet. Melalui e-commerce, memungkinkan kita dengan sedikit usaha memperoleh apa saja yang kita butuhkan. Hampir semua jenis jasa dapat dicari melalui internet, seperti membeli pakaian, furnitur, kebutuhan sehari-hari seperti peralatan rumah tangga, dan makanan (Peng dan Tao, 2018).

Menurut Negadeepa (2015), internet adalah pasar yang hampir sempurna karena informasi dapat diterima secara cepat dan pembeli dapat membandingkan penawaran dari penjual di seluruh dunia. Hasilnya adalah persaingan harga menjadi ketat dan loyalitas merek menjadi rentan karena persaingan. Mengingat pengurangan asimetri informasi antara penjual dan pembeli, ada minat dalam memahami dasar loyalitas pelanggan dalam lingkungan online.

Potensi internet sebagai media pemasaran dan perdagangan telah banyak dibicarakan, khususnya oleh para pemain dalam bidang pemasaran. Pembicaraan tersebut menghasilkan suatu pandangan mengenai perdagangan melalui internet, sehingga menyebabkan seseorang melakukan preferensi belanja online. Preferensi belanja online adalah kecenderungan seseorang untuk melakukan pembelian melalui internet (Grant \& Meadows, 2008).

Adapun hal yang menjadi dasar bagi konsumen untuk melakukan pembelian melalui toko online, salah satunya adalah display/tampilan pada toko online. Menurut Burinskiene dan Daskevie (2014) menyatakan bahwa terdapat beberapa hal yang harus terdapat pada toko online, seperti bentuk homepage sebagai tampilan awal dari toko online, kedua adalah kualitas grafis dari bentuk homepage itu sendiri, peletakan produk unggulan, 
fungsi tombol search, pengkategorian produk yang ditampilkan, terdapatnya link dengan web serupa sebagai referensi untuk membandingkan produk, terdapatnya tambahan video, deskripsi produk yang cukup jelas, terdapatnya informasi pembuka serta adanya nomer telepon atau e-mail yang dapat dihubungi serta adanya penawaran spesial. Hal-hal tersebut merupakan beberapa faktor yang harus dipenuhi oleh toko online untuk dapat meningkatkan kinerjanya.

Selain display/tampilan pada toko online, promosi penjualan dapat meningkatkan pejualan dari suatu produk. Melalui promosi penjualan dimaksudkan sebagai kegiatan promosi selain periklanan, personalselling, maupun publisitas (Sinha \& Verma, 2015). Tujuan dari promosi penjualan sangat beraneka ragam. Melalui promosi penjualan, perusahaan atau onlinestore dapat menarik pelanggan baru mempengaruhi pelanggannya untuk mencoba produk baru, mendorong pelanggan membeli lebih banyak menyerang aktivitas promosi pesaing, meningkatkan impulse buying (pembelian tanpa rencana sebelumnnya), atau mengupayakan kerjasama yang lebih erat dengan pengecer (Mendez dkk, 2015).

Menurut Yoebrilianti (2018) promosi penjualan harus menarik perhatian, mendapatkan dan mendorong minat, membangkitkan keinginan, dan menghasilkan tindakan. Dalam membangun program komunikasi yang efektif, aspek terpenting adalah memahami proses terjadinya respon dari konsumen, misalnya dalam hal konsumen melakukan pembelian suatu produk, maka diperlukan pemahaman mengenai usaha promosi yang dapat mempengaruhi respon konsumen tersebut.

Selainitu kualitas produk menjadi hal yang penting bagi konsumen, menurut Lee dan Shin (2014) kualitas produk adalah karakteristik dari produk dan jasa yang menunjang kemampuannya untuk memuaskan kebutuhan konsumen. Berdasarkan kemampuan suatu produk untuk menampilkan fungsi-fungsinya. Dalam hal ini fungsi-fungsi produk tersebut sangat terlihat dan berbeda dibandingkan para pesaing. Menurut Mendez dkk (2015) menyatakan bahwa kualitas tersebut mempunyai standar yang memang tercermin dalam produk.

Ketiga variabel diatas yaitu display, promosi penjualan dan kualitas produk merupakan variabel yang menjadi penentu dalam keloyalan konsumen dalam membeli suatu produk melalui toko online. Menurut Setiawan dkk (2016) menyatakan loyalitas adalah komitmen pelanggan bertahan secara mendalam untuk berlangganan kembali atau melakukan pembelian ulang produk / jasa terpilih secara konsisten di masa yang akan datang, meskipun pengaruh situasi dan usaha-usaha pemasaran mempunyai potensi untuk menyebabkan perilaku.

Loyalitas secara harfiah diartikan kesetiaan, yaitu kesetiaan seseorang terhadap suatu objek. Jadi loyalitas merek adalah respon keperilakuan (yaitu pembelian) yang bersifat bias (nonrandom) yang terungkap secara terus menerus oleh unit pengambil keputusan dengan memperhatikan satu atau beberapa merek alternatif dari sejumlah merek sejenis dan merupakan fungsi proses psikologis atau pengambil keputusan, evaluative (Jain dkk, 2018).

Dalam bentuk hubungan antara display/tampilan, promosi penjualan dan kualitas produk terhadap loyalitas pelanggan di mediasi oleh kepuasan konsumen untuk melihat 
keterikatan antara variabel independen terhadap variabel dependen. Kepuasan terhadap produk yang ditawarkan akan menciptakan loyalitas pelanggan untuk melakukan pembelian kembali. Hal ini ditujukan dengan pelayanan yang diberikan dan juga produk sesuai dengan ekspektasi pelanggan, sehingga pelanggan merasa puas dan kesediaan pelanggan untuk menyebarkan informasi terbaik mengenai produk tersebut (Lestari dan Yulianto, 2018). Kepuasan konsumen melalui display/tampilan, promosi penjualan dan kualitas produk yang diberikan oleh toko online berpengaruh atau tidaknya pada loyalitas pelanggan, diukur melalui kepuasan dengan layanan bisnis online, sehingga dapat dilihat keterkaitan diantara variabel independen dan variabel intervening dalam perannya untuk memberikan pengaruh atau tidak terhadap loyalitas pelanggan.

Penelitian ini dilakukan di Kota Bandung yang sampelnya merupakan masyarakat pengguna media sosial aktif di Kota Bandung dan berusia sekitar 18 - 34 tahun. Berdasarkan Hootsuite (2019) profil pengguna media sosial berdasarkan usia laki laki dan perempuan di dominasi yang berumur pada 18 tahun sampai dengan 34 tahun. Usia tersebut termasuk dalam usia produktif pengguna media sosial di Indonesia. Melalui penjabaran di atas penulis ingin meneliti pengaruh display, promosi penjualan dan kualitas produk pada toko online terhadap loyalitas konsumen dengan kepuasan pelanggan sebagai variabel intervening.

\subsection{Rumusan Masalah}

Berdasarkan pada variabel yang diteliti, maka permasalahan dalam penelitian ini adalah:

a. Bagaimana pengaruh display, promosi penjualan serta kualitas produk pada toko online terhadap loyalitas konsumen secara parsial?

b. Bagaimana pengaruh display, promosi penjualan serta kualitas produk pada toko online terhadap loyalitas konsumen secara simultan?

c. Bagaimana pengaruh display toko online, promosi penjualan serta kualitas produk pada toko online terhadap loyalitas konsumen dengan kepuasan pelanggan sebagai variabel intervening secara simultan?

\subsection{Tujuan Penelitian}

a. Untuk mengetahui pengaruh secara parsial display, promosi penjualan serta kualitas produk pada toko online terhadap loyalitas konsumen.

b. Untuk mengetahui pengaruh secara simultan display, promosi penjualan serta kualitas produk pada toko online terhadap loyalitas konsumen.

c. Untuk mengetahui pengaruh secara simultan display toko online, promosi penjualan serta kualitas produk pada toko online terhadap loyalitas konsumen dengan kepuasan pelanggan sebagai variabel intervening.

\section{TINJAUAN PUSTAKA}

\subsection{Aktifitas Pembelanjaan secara Online}

Belanja online merupakan bagian dari e-commerce yang menuju pada aktivitas bisnis dengan memanfaatkan teknologi komunikasi internet sebagai mediumnya (Grant \& 
Meadows, 2008). E-Commerce dapat didefinisikan sebagai segala bentuk transaksi perdagangan atau perniagaan barang atau jasa (trade of goods and services) dengan menggunakan media elektronik. Didalam E-Commerce itu sendiri terdapat perdagangan via internet seperti dalam bussiness to consumer (B2C), bussines to bussines (B2B) dan perdagangan dengan pertukaran data terstruktur secara elektronik (Masoud, 2013).

Pandangan tentang e-commerce atau yang sering dikenal dengan onlineshopping atau belanja online adalah pengunaan komputer dan internet dengan Web Browser untuk membeli dan menjual produk (Harahap \& Amanah, 2018). Belanja online bergantung pada sumber daya internet dan banyak teknologi informasinya yang mendukung setiap langkah dari proses jual beli.

Ada banyak alasan mengapa orang berbelanja online, sebagai contoh, konsumen bisa membeli barang kapan saja tanpa pergi ke toko; mereka dapat produk yang sama dengan harga yang lebih rendah dengan membandingkan berbagai situs web pada saat bersamaan; mereka kadang ingin menghindari tekanan saat berinteraksi tatap muka dengan tenaga penjualan; mereka dapat menghindari kemacetan lalu lintas di toko, dll. Faktorfaktor ini dapat diringkas menjadi empat kategori, kenyamanan, informasi, produk dan layanan yang tersedia, efisiensi biaya dan waktu (Katawetawaraks \& Wang, 2011).

\subsection{Kemenarikan pada Desain Website}

Tidak jauh berbeda dari belanja secara offline, komunikasi pemasaran perlu juga ditampilkan secara lugas dan menarik guna membujuk calon konsumen agar berminat membeli produk yang ditawarkan. Ujwala dan Vinay (2014) mengemukakan bahwa salah bentuk komunikasi pemasaran adalah iklan yang harus memiliki kemenarikan khas yang mampu membuat calon konsumen tertarik pada produk yang ditawarkan. Untuk ini, fungsi iklan tersebut adalah harus mampu menginformasikan manfaat produk yang ditawarkan, memunculkan rasa percaya dan menarik hati para calon konsumen.

Desain website, sebagai salah satu cara mewujudkan daya tarik iklan. Dikatakan menarik apabila isi dan tampilannya mampu menarik pasar sasaran mampu menarik minat para clickers' dalam akun tersebut. Ujwala dan Vinay (2014) mengemukakan bahwa teknik yang memudahkan akses dan publikasi informasi adalah menggunakan interaksi sosial melalui sosial media. Diseminasi informasi melalui sosial media selain mulai menjamur karena tingginya ikatan sosial dari pengguna juga merupakan cara baru yang lebih efektif dalam pencarian informasi. Dalam penyebaran informasi inilah, kemenarikan desain website menjadi salah satu pemandu yang handal guna mendorong calon konsumen untuk mengunjungi akun yang ada.

Oleh karenanya semakin menarik desain website diharapkan mampu memantabkan keputusan berbelanja online. Selain itu kemenarikan desain website akan memengaruhi keinginan seseorang dalam melakukan belanja online (Farah dkk, 2018). Keinginan tersebut merupakan perwujudan dari kepercayaan seseorang atas transaksi yang dilakukan (Masoud, 2013).

\subsection{Displaypada Toko Online}

Aktifitas belanja secara online merupakan bentuk bisnis $e$-commerce yang penting. Apabila penjual online ingin mengejar pembeli online maka mereka harus mengerti apa 
yang menentukan seorang pembeli online untuk melakukan pembelian. Berdasarkan penelitian yang dilakukan oleh Katawetawaraks dan Wang (2011) serta Ujwala dan Vinay (2014) menyatakan bahwa hal yang menjadi penentu dalam display toko online adalah meliputi:

(1) User Friendly Website: (a) konsumen bisa terpengaruh melalui foto dan desain grafis yang dipajang pada situs web dengan menampilkannya secara menarik dan lebih tepat sasaran sesuai dengan kategori produknya. (b) menampilkan informasi produk yang lebih bervariasi dan berguna. (c) kemudahan dalam mengakses web dimana konsumen tidak kesulitan untuk mencari produk yang diinginkan, dalam hal ini adalah berupa pengkategorian produk yang ditampilkan .

(2) Online Service: (a) toko online seharusnya menyediakan pelayanan nilai tambah kepada konsumen dengan memiliki layanan customer service berupa saluran feedback dengan konsumen berupa e-mail atau nomer telepon yang dapat dihubungi sehingga akan memudahkan konsumen saat akan melakukan pemesanan suatu produk.

Selain yang dijelaskan di atas, menurut penelitian yang dilakukan oleh Burinskiene dkk (2014) menyatakan hal yang serupa bahwa desain grafik termasuk di dalamnya, yaitu penggunaan foto produk yang baik dapat menarik perhatian konsumen dalam mengunjungi suatu web. Selain itu juga penjelasan suatu produk serta pengkategoriannya yang jelas dapat memudahkan konsumen untuk memahami suatu produk.

\subsection{Promosi Penjualan secara Online}

Menurut Neha \& Manoj (2013) promosi penjualan telah dianggap sebagai teknik promosi yang paling merangsang untuk mempengaruhi keputusan pembelian. Menurut Strauss \& Frost dalam Himawan \& Abduh (2015) promosi penjualan adalah insentif jangka pendek berupa hadiah atau uang yang memfasilitasi perpindahan produk dari produsen ke pengguna akhir. Menurut Shamout (2016) adalah teknik yang digunakan oleh pemasar secara sementara untuk menciptakan barang atau jasa yang menarik untuk mendorong pelanggan untuk membeli barang atau jasa tersebut dalam periode waktu tertentu dengan memberikan lebih banyak manfaat.

Menurut definisi di atas, kesimpulan dari promosi penjualan online adalah teknik yang digunakan oleh pemasar untuk merangsang pelanggan untuk membeli suatu produk.Dalam hal ini, ada tujuh dimensi promosi penjualan online berdasarkan pada Neha dan Manoj (2013) sebagai berikut:(1) Kupon, tawarkan sertifikat yang memberikan pengurangan harga saat pembelian. (2) Potongan harga, pemberian uang kembali pada produk dari produsen pada pembelian. (3) Uji Coba Gratis, memberi konsumen kesempatan untuk menggunakan produk dengan memberikan porsi kecil gratis dari produk untuk diuji konsumen. (4). Premium, tawarkan peningkatan kuantitas produk tanpa kenaikan harga normal. (5) Kontes, memberikan kesempatan untuk memenangkan hadiah besar melalui keterampilan. (6) Sweeptakes, memberikan kesempatan untuk memenangkan hadiah besar berdasarkan kebetulan. (7) Paket Harga, menawarkan pengurangan harga normal suatu produk.

Menurut Negadeepa (2015) dan Huang dalam Himawan \& Abduh (2015)untuk mengimplementasikan kegiatan promosi penjualan online, ada beberapa strategi promosi 
online populer yang dapat digunakan untuk mempengaruhi pelanggan membeli, yaitu (1) Diskon harga online adalah pengurangan penjualan asli dengan persentase tertentu sementara paket bonus adalah transaksi di mana konsumen menerima lebih banyak untuk harga asli. (2) Kupon onlineadalah tawaran sertifikat yang akan memerlukan kode khusus untuk dimasukkan selama tahap checkout agar dapat berlaku untuk pengurangan harga. (3) Pengiriman gratis ditawarkan sebagai promosi, baik dengan, atau tanpa kupon. Di sisi lain, kualitas layanan online penting untuk dianalisis dalam strategi pemasaran, pelanggan membeli produk dalam e-commerce / online juga mempertimbangkan kualitas layanan itu sendiri.

\subsection{Kualitas produk pada toko online}

Review dari pembeli online adalah sumber yang penting untuk mendapatkan informasi suatu produk (Huang, Chen, Yen, \& Tran, 2015). Produk adalah semua yang bisa ditawarkan dipasar untuk mendapatkan perhatian, permintaan, pemakaian atau konsumsi yang dapat memenuhi keinginan atau kebutuhan konsumen. Kualitas produk mencerminkan kemampuan produk untuk menjalankan tugasnya yang mencakup daya tahan, kehandalan, kemajuan, kekuatan, kemudahan dalam pengemasan, dan reparasi produk dan ciri-ciri lainnya.

Kualitas produk menurut Lee dan Shin (2014) adalah karakteristik dari produk dan jasa yang menunjang kemampuannya untuk memuaskan kebutuhan konsumen. Terdapat dua variasi pendekatan dalam kualitas produk, yaitu pendekatan kualitas yang obyektif dan kualitas secara subyektif. Pendekatan obyektif menekankan pada pandangan terhadap kualitas secara internal, melalui pendekatan produksi dan penawaran, sedangkan pendekatan subyektif menekankan pada kualitas secara eksternal yaitu kesesuaian produk yang dihasilkan dengan pandangan eksternal yaitu keinginan atau harapan konsumen.

Al-Jahwari dkk (2018) mengatakan bahwa dimensi dari kualitas produk dibagi menjadi 2 bagian, yaitu sebagai berikut ini :

1. Level (performancequality) adalah kemampuan suatu produk untuk menampilkan fungsi-fungsinya. Dalam hal ini fungsi-fungsi produk tersebut sangat terlihat dan berbeda dibandingkan para pesaing. Performancequality dapat diukur melalui kenyamanan (comfortable), yaitu kemampuan produk memberikan, kemudahan dan kenyamanan bagi penggunanya; ketahanan (durability), yaitu umur produk atau seberapa lama produk tersebut bertahan sampai akhirnya harus diganti; model atau desain (design) yaitu, produk mempunyai model dan nilai kesesuaian dengan selera konsumen; kualitas bahan (material) yaitu, produk terbuat dari bahan yang berkualitas dan mendukung fungsi produk.

2. Consistency (conformance quality)adalah konsisten atau stabil dalam memberikan kualitas yang diharapkan konsumen, artinya kualitas tersebut mempunyai standar yang memang tercermin dalam produk. Conformance quality dijelaskan dalam bebas dari cacat dan kegagalan (freedom from defects), bebas dari kesalahan-kesalahan dalam proses produksinya; dan konsisten (concistency) yaitu mempertahankan kinerja produk untuk diberikan kepada pelanggan, sesuai dengan yang diharapkan. 


\subsection{Kepuasan Pelanggan}

Alharbi dan Alhider (2018) mendefinisikan kepuasan pelanggan sebagai "sejauh mana anggapan kinerja produk atau jasa memenuhi harapan pembeli". Bila kinerja produk lebih rendah daripada harapan pelanggan, maka pelanggan tidak puas, bila kinerja sesuai atau melebihi harapan pelanggan, maka pelanggan merasa puas. Agustine dan Koeshartono (2014) mendefinisikan kepuasan pelanggan sebagai "suatu tanggapan emosional pada evaluasi pengalaman konsumsi suatu produk atau jasa".

Rahadi (2013) menunjukkan bahwa perusahaan yang menyediakan kualitas layanan yang baik dapat benar-benar memenuhi beragam kebutuhan pelanggan dan kepuasan pelanggan adalah evaluasi keseluruhan produk dan layanan berdasarkan pengalaman masa lalu pelanggan. Tjahjaningsih (2013) menjelaskan hal itu kepuasan pelanggan dianggap sebagai evaluasi keseluruhan dari produk nyata dan produk tidak berwujud.

Pada penelitian ini kepuasan pelanggan diukur melalui survei kepuasan konsumen dengan pengukuran indikator kepuasan pelanggan sebagai berikut ( $\mathrm{Wu}, 2013)$ :

a. Puas dengan layanan bisnis online. Suatu perusahaan yang mampu memberikan layanan yang baik akan mampu menciptakan konsumen yang puas. Layanan yang baik juga harus dilakukan pada bisnis online.

b. Puas dengan pembelian melalui bisnis online. Kemudahan dan kecepatan pembelian melalui media online memberikan kontribusi positif pada peningkatan kepuasan konsumen.

c. Puas dengan produk yang dijual bisnis online. Pihak manajemen bisnis online harus memberikan informasi yang detail mengenai produk yang dijual. Hal ini dilakukan dengan tujuan agar konsumen dapat mengetahui dengan baik karakteristik dari produk yang dijual. Hal ini penting untuk dilakukan dengan tujuan agar konsumen puas setelah menerima produk yang dibeli karena sesuai dengan harapannya.

d. Puas dengan lingkungan belanja bisnis online. Sistem pembelian di bisnis online harus dapat memberikan kenyaman yang tinggi bagi konsumen. Lingkungan bisnis yang baik akan memberikan kontribusi pada kepuasan konsumen

\subsection{Loyalitas Konsumen}

Menurut Hatta dkk (2018), loyalitas adalah komitmen pelanggan bertahan secara mendalam untuk berlangganan kembali atau melakukan pembelian ulang produk / jasa terpilih secara konsisten di masa yang akan datang, meskipun pengaruh situasi dan usahausaha pemasaran mempunyai potensi untuk menyebabkan perilaku.

\subsection{Memahami Loyalitas Pelanggan Online}

Sebenarnya, antara loyalitas pelanggan dan loyalitas pelanggan online memiliki perspektif definisi yang berbeda dari para ahli. Menurut Ludin dan Cheng (2014) mendefinisikan $e$-loyalty sebagai sikap yang disukai pelanggan terhadap e-commerce yang mengarah pada perilaku pembelian berulang. 
Menurut Winnie (2014), loyalitas pelanggan online ada di sekitar konsumen yang cenderung membeli kembali dari situs web dan e-retailer yang sama, daripada beralih ke situs web lain. Menurut Chi, Jiun \& Lin (2015) adalah komitmen untuk secara konsisten mengunjungi kembali situs web karena preferensi untuk berbelanja situs web itu tanpa beralih ke situs web lain. Jadi, kesimpulan dari definisi di atas loyalitas pelanggan online adalah membeli produk online berulang kali di merek yang sama atau situs web $e$-retailer yang sama.

\subsection{Karakteristik Loyalitas Pelanggan Online}

Wan dan Huang (2010) dalam Tjahjaningsih (2013) menunjukkan bahwa loyalitas pelanggan dapat dilihat melalui sikap dan perilaku. Sikap termasuk niat untuk membeli kembali produk lain di perusahaan dan niat untuk direkomendasikan kembali kepada yang lain. Perilaku termasuk membeli kembali produk, membeli produk lain dari perusahaan dan merekomendasikan kepada yang lain.

Dalam pemasaran, loyalitas konsumen dilihat sebagai masalah yang penting yang mempengaruhi bisnis dalam pelaksanaan dan performanya. Terdapat banyak pengertian dan literatur atas loyalitas konsumen untuk mengukur loyalitas (Jain dkk. 2018; Momotaz \& Hasan, 2018). Berdasarkan pendekatan antitudinal dan behavioural bahwa loyalitas mengikuti empat tahap, yaitu kognitif, afektif, konatif dan tindakan. Secara rinci dijelaskan sebagai berikut:

(1) Loyalitas Kognitif yaitu pelanggan yang mempunyai loyalitas tahap pertama ini menggunakan informasi keunggulan suatu produk atas produk lainnya. Loyalitas kognitif lebih didasarkan pada karakteristik fungsional, terutama biaya, manfaat dan kualitas. (2) Loyalitas Afektif yaitu sikap merupakan fungsi dari kognisi pada periode awal pembelian (masa sebelum konsumsi) dan merupakan fungsi dari sikap sebelumnya ditambah dengan kepuasan di periode berikutnya (masa setelah konsumsi). Munculnya loyalitas afektif ini didorong oleh faktor kepuasan yang menimbulkan kesukaan dan menjadikan objek sebagai preferensi. Kepuasan pelanggan berkorelasi tinggi dengan niat pembelian ulang di waktu mendatang. (3) Loyalitas Konatif yaitu menunjukkan suatu niat atau komitmen untuk melakukan sesuatu. Niat merupakan fungsi dari niat sebelumnya (pada masa sebelum konsumsi) dan sikap pada masa setelah konsumsi. Maka loyalitas konatif merupakan suatu loyalitas yang mencakup komitmen mendalam untuk melakukan pembelian. (4) Loyalitas Tindakan yaituaspek konatif atau niat untuk melakukan berkembang menjadi perilaku dan tindakan.

\subsection{Model Penelitian}

Dengan seiring perkembangan teknologi, memunculkan berbagai peluang baru dalam usaha salah satunya adalah e-commerce. Menurut Shahriari, Shahriari, \& Gheiji (2016) E-commerce adalah perdagangan produk atau layanan menggunakan jaringan komputer, seperti Internet. Proses pembelian dan penjualan produk atau layanan menggunakan transmisi data elektronik melalui internet, sehingga kemenarikan dari suatu website sangatlah penting untuk menarik perhatian konsumen (Ujwala \& Vinay, 2014). Selain itu sebuah display pada website juga harus dapat diakses dengan mudah dan mampu 
memberikan informasi yang cukup atas suatu produk yang ditawarkan (Katawetawaraks \& Wang, 2011).

Selain display yang menarik dan mudah untuk diakses, promosi penjualan online juga sangat perlu diperhatikan, melalui pemberin diskon harga, kupon online dan pengiriman barang secara gratis untuk dapat meningkatkan loyalitas konsumen (Himawan \& Abduh, 2015). Kemudian kualitas produk juga harus diperhatikan, menurut Lee dan Shin (2014) kualitas produk adalah karakteristik dari produk dan jasa yang menunjang kemampuannya untuk memuaskan kebutuhan konsumen. Berdasarkan ketiga variabel independen tersebut loyalitas konsumen dapat terbentuk dengan baik, dimana menurut Ludin dan Cheng (2014) mendefinisikan e-loyalty sebagai sikap yang disukai pelanggan terhadap e-commerce yang mengarah pada perilaku pembelian berulang. Dengan memasukkan variabel intervening kepuasan pelanggan, penulis ingin mengetahui pengaruh yang ditimbulkan.

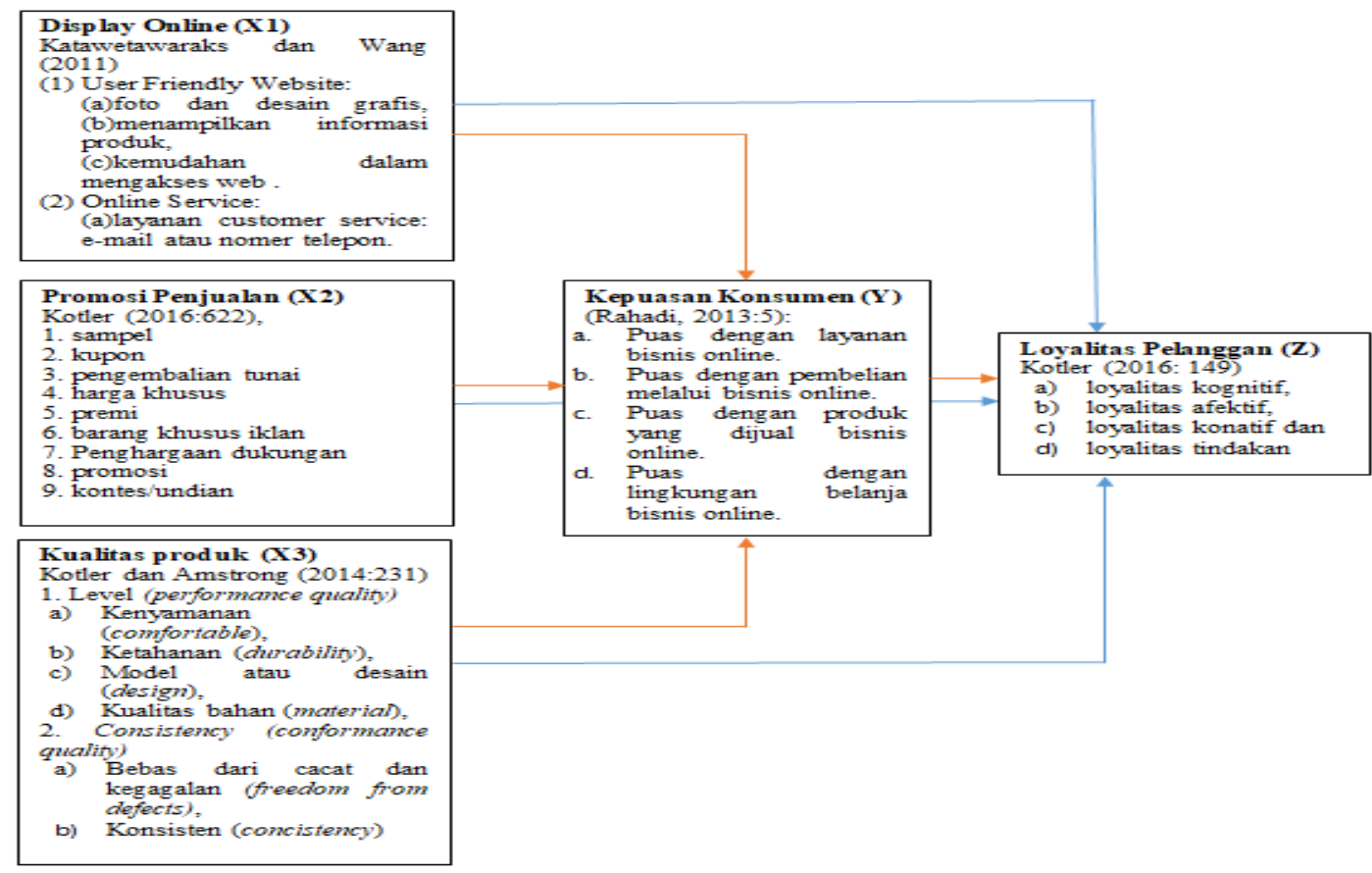

Gambar 2.1. Kerangka pemikiraan "Pengaruh Display, Promosi penjualan, Kualitas Produk pada Toko Online terhadap Loyalitas Konsumen dengan Kepuasan Pelanggan sebagai Variabel Intervening"

\section{Keterangan :}

H1 : Display Toko Online berpengaruh signifikan terhadap Loyalitas Konsumen.

H2 : Promosi Penjualan berpengaruh signifikan terhadap Loyalitas Konsumen.

H3 : Kualitas Produk berpengaruh signifikan terhadap Loyalitas Konsumen.

H4 : Display, Promosi Penjualan, Kualitas Produk berpengaruh signifikan terhadap Loyalitas Konsumen.

H5 : Display, Promosi Penjualan, Kualitas Produk berpengaruh signifikan terhadap Loyalitas Konsumen dengan Kepuasan Konsumen sebagai variabel intervening. 


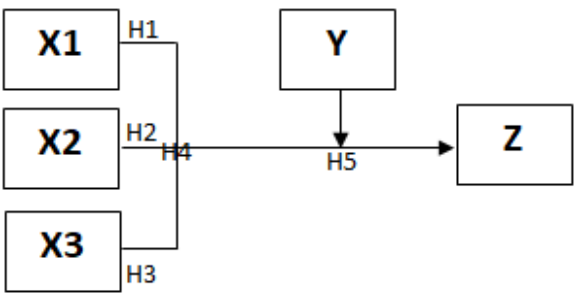

Gambar 2.2. Kerangka Hipotesis "Pengaruh Display, Promosi penjualan, Kualitas Produk pada Toko Online terhadap Loyalitas Konsumen dengan Kepuasan Pelanggan sebagai Variabel Intervening"

Dimana, X1 :Display

$\mathrm{X} 2$ : Promosi Penjualan

$\mathrm{X} 3$ :Kualitas Produk

Y :Kepuasan Pelanggan

$\mathrm{Z}$ :Loyalitas Konsumen

METODE

Penelitian ini meneliti mengenai pengaruh display, promosi penjualan dan kualitas produk pada toko online terhadap loyalitas konsumen dengan kepuasan pelanggan sebagai variabel intervening. Teknik analisis data kuantitatif digunakan dengan pengisian kuesioner berskala Likert (1-5), data yang terkumpul diolah dengan menggunakan analisis regresi.

Metode deskriptif digunakan untuk mendeskripsikan atau menguraikan permasalahan yang berkaitan dengan pertanyaan terhadap variabel independen, yaitu mendeskripsikan display, promosi penjualan dan kualitas produk serta variabel dependen, yaitu loyalitas konsumen dan variabel intervening, yaitu kepuasan pelanggan. Sedangkan analisis verifikatif adalah analisis model dan pembuktian yang berguna untuk mencari kebenaran dari hipotesis yang diajukan.

Populasi dari penelitian ini adalah masyarakat pengguna media social aktif di Kota Bandung yang berusia 18-34 tahun. Teknik pengambilan sampel dalam penelitian ini menggunakan non probability sampling dengan metode insidental sampling hal ini dikarenakan peneliti tidak mengetahui secara pasti jumlah pengguna media sosial yang berada di Kota Bandung. Perhitungan sampel menggunakan persamaan rumus Bernoulli (Zikmund, 2010:436) yaitu :

$$
\frac{\mathbf{n} \geq(1,96)^{2} \cdot 0,5 \cdot 0,5}{0,1^{2}} \quad=\mathbf{9 6 , 0 4}
$$

Dibulatkan menjadi 100 sampel.

Akan tetapi setelah melakukan penyebaran kuisioner, yang mengembalikan kuesioner pada peneliti sebanyak 116 responden yang berumur 18-34 tahun. 


\section{HASIL DAN PEMBAHASAN}

\subsection{Hasil Validitas dan Reliabilitas}

Berikut adalah tabel hasil perhitungan validitas dan reliabilitas :

\begin{tabular}{|c|c|c|c|c|}
\hline Variabel & $\begin{array}{c}\text { Skor } \\
\text { Validitas }\end{array}$ & Hasil & $\begin{array}{c}\text { Skor } \\
\text { Reliabilitas }\end{array}$ & Hasil \\
\hline Variabel Display & & & & \multirow{5}{*}{ RELIABEL } \\
\hline Foto dan Desain Grafis & 0,798 & VAIID & \multirow{4}{*}{0,794} & \\
\hline Info Produk & 0,833 & VALID & & \\
\hline Kemudahan Akses & 0,639 & VAIID & & \\
\hline Customer Service Mudah Dihubungi & 0,426 & VALID & & \\
\hline Variabel Promosi Penjualan & & & & \\
\hline Diskon Harga & 0,701 & VAIID & \multirow{3}{*}{0,787} & \multirow{4}{*}{ RELIABEL } \\
\hline Kupon Online & 0,555 & VAIID & & \\
\hline Pengiriman Gratis & 0,668 & VAIID & & \\
\hline Variabel Kualitas Produk & & & \multirow{7}{*}{0,885} & \\
\hline Kenyamanan Produk & 0,726 & VAIID & & \multirow{6}{*}{ RELIABEI } \\
\hline Ketahanan Produk & 0,450 & VAIID & & \\
\hline Desain Produk & 0,843 & VAIID & & \\
\hline Kualitas Bahan Produk & 0,424 & VAIID & & \\
\hline Produk Bebas Cacat & 0,409 & VAIID & & \\
\hline Produk Konsisten & 0,718 & VAIID & & \\
\hline Kepuasan Pelanggan & & & \multirow{5}{*}{0,618} & \multirow{5}{*}{ RELIABEL } \\
\hline Puas dengan Layanan & 0,691 & VALID & & \\
\hline Puas dengan Pembelian & 0,752 & VAIID & & \\
\hline Puas dengan Produk & 0,814 & VAIID & & \\
\hline Puas dengan Lingkungan Belanja & 0,478 & VAIID & & \\
\hline Loyalitas Konsumen & & & \multirow{5}{*}{0,686} & \multirow{5}{*}{ RELIABEL } \\
\hline Loyalitas Kognitif & 0,672 & VAIID & & \\
\hline Loyalitas Afektif & 0,637 & VALID & & \\
\hline Loyalitas Konatif & 0,822 & VAIID & & \\
\hline Loyalitas Tindakan & 0,754 & VALID & & \\
\hline
\end{tabular}

Tabel 4.1. Hasil Perhitungan Validitas dan Realibilitas

Untuk mengukur validitas digunakan rumus Pearson Product Momentdengan bantuan SPSS 25. Hasil dari uji statistik Cronbach Aplha $(\alpha)$ ini akan menentukan indikator dari pernyataan yang digunakan dalam penelitian ini reliabel digunakan atau tidak. Dikatakan reliabel jika memberikan nilai Cronbach alpha> 0,6.

Tabel 4.1 di atas memperlihatkan bahwa semua indikator valid dan reliabel dengan signifikan pada 0,00. Dengan rata-rata perolehan skor terendah untuk skor validitas pada 0,409 untuk indicator produk bebas cacat. Pernyataan tersebut mendapatan tingkat hubungan yang sedang dengan responden, dan yang tertinggi adalah 0,843 untuk indikator model/desain suatu produk. Pernyataan tersebut mendapatkan tingkat hubungan yang sangat kuat dengan responden.

Pada hasil perhitungan didapatkan skor terendah 0,618 pada kepuasan pelanggan dan skor tertinggi pada kualitas produk sebesar 0,885 di mana rentang diatas 0,6 sehingga dinyatakan reliabel.

\subsection{Hasil Perhitungan Display, Promosi Penjualan dan Kualitas Produk Terhadap}

\section{Loyalitas Konsumen Secara Parsial}

Berikut ini adalah hasil perhitungan variabel Display, Promosi Penjualan dan Kualitas Produk terhadap Loyalitas Konsumen secara parsial :

\begin{tabular}{|l|c|c|c|c|c|}
\hline \multicolumn{1}{|c|}{$\begin{array}{c}\text { Hubungan Antar } \\
\text { Variabel }\end{array}$} & $\begin{array}{c}\text { Unstandardized } \\
\text { Coefficients B }\end{array}$ & Significant & R Square & $\begin{array}{c}\text { Nilai } \\
\text { F }\end{array}$ & $\begin{array}{c}\text { Nilai } \\
\text { thitung }\end{array}$ \\
\hline $\begin{array}{l}\text { Display Toko Online } \\
\text { (X1) Terhadap Loyalitas } \\
\text { Konsumen (Z) }\end{array}$ & $-0,530$ & 0,339 & & & $-0,960$ \\
\cline { 1 - 3 } $\begin{array}{l}\text { Promosi Penjualan (X2) } \\
\text { Terhadap Loyalitas } \\
\text { Konsumen (Z) }\end{array}$ & 0,256 & 0,006 & \multirow{2}{*}{0,378} & 22,704 & 2,789 \\
\cline { 1 - 2 } $\begin{array}{l}\text { Kualitas Produk (X3) } \\
\text { Terhadap Loyalitas } \\
\text { Konsumen (Z) }\end{array}$ & 0,278 & 0,000 & & & 5,716 \\
\hline
\end{tabular}

Tabel 4.2. Hasil Perhitungan Secara Parsial 


\subsection{Hasil Perhitungan Display, Promosi Penjualan dan Kualitas Produk Terhadap Loyalitas Konsumen Secara Simultan}

Berikut ini adalah hasil perhitungan variabel Display, Promosi Penjualan dan Kualitas Produk Terhadap Loyalitas Konsumen Secara Simultan :

\begin{tabular}{|l|c|c|c|c|c|}
\hline $\begin{array}{c}\text { Hubungan Antar } \\
\text { Variabel }\end{array}$ & $\begin{array}{c}\text { Unstandardized } \\
\text { Coefficients B }\end{array}$ & Significant & R Square & Nilai F & $\begin{array}{c}\text { Nilai T } \\
\text { Hitung }\end{array}$ \\
\hline $\begin{array}{l}\text { Display (X1)Terhadap } \\
\text { Loyalitas Konsumen(Z) }\end{array}$ & $-0,056$ & 0,352 & 0,008 & 0,874 & 0,935 \\
\hline $\begin{array}{l}\text { Promosi Penjualan (X2) } \\
\text { Terhadap Loyalitas } \\
\text { Konsumen (Z) }\end{array}$ & 0,447 & 0,000 & 0,190 & 26,683 & 5,166 \\
\hline $\begin{array}{l}\text { Kualitas Produk(X3) } \\
\text { Terhadap Loyalitas } \\
\text { Konsumen (Z) }\end{array}$ & 0,316 & 0,000 & 0,298 & 48,379 & 6,955 \\
\hline
\end{tabular}

Tabel 4.3. Hasil Perhitungan Secara Simultan

\subsection{Perhitungan Path Analysis}

Pada perhitungan untuk melihat pengaruh variabel intervening, maka digunakan metode analisis jalur (Path Analysis). Pengujian hipotesis intervening dapat dilakukan dengan prosedur yang dikembangkan oleh sobel (1982) dan dikenal dengan uji sobel (Sobel Test). Uji sobel dilakukan dengan cara menguji kekuatan pengaruh pengaruh tidak langsung $\mathrm{X}$ ke $\mathrm{Z}$ lewat $\mathrm{Y}$. Pengaruh tidak langsung $\mathrm{X}$ ke $\mathrm{Z}$ lewat $\mathrm{Y}$ dihitung dengan cara mengalikan jalur $\mathrm{X}-\mathrm{Y}(\mathrm{p} 2)$ dengan jalur $\mathrm{Y}-\mathrm{Z}(\mathrm{p} 3)$ atau jalur $\mathrm{p} 2 \mathrm{x}$ p3. Jadi koefisien $\mathrm{p} 2 \mathrm{x}$ $\mathrm{p} 3=(\mathrm{c} '-\mathrm{p} 1)$, dimana $\mathrm{p} 1$ adalah pengaruh $\mathrm{X}$ terhadap $\mathrm{Z}$ tanpa mengontrol $\mathrm{Y}$, sedangkan c' adalah koefisien pengaruh $\mathrm{X}$ terhadap $\mathrm{Z}$ setelah mengontrol $\mathrm{Y}$. Berikut merupakan penjabaran rumus variabel dan gambar analisis jalur yang akan diuji dengan menggunakan Sobel Test :

\section{Pengaruh langsung Display, Promosi Penjualan dan Kualitas Produk ke $\quad=p 1$}

Loyalitas Konsumen.

Pengaruh tak langsung Display, Promosi Penjualan dan Kualitas Produk = p2 x p3 ke Kepuasan Pelanggan ke Loyalitas Konsumen

Total pengaruh (korelasi Pengaruh langsung Display, Promosi Penjualan = p1 + (p2 x p3) dan Kualitas Produk ke Loyalitas Konsumen)

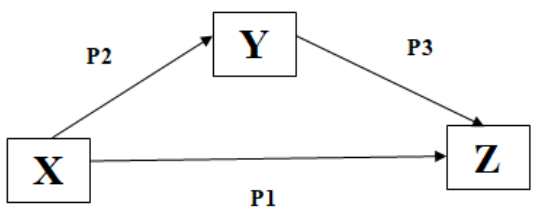

Gambar 4.1. Model Analisis Jalur Pengaruh display, promosi penjualan dan kualitas produk pada toko online terhadap loyalitas konsumen dengan kepuasan pelanggan sebagai variabel intervening. 
Berikut ini adalah perhitungan koefisien yang didapatkan dengan bantuan SPSS 25:

\begin{tabular}{|c|c|c|c|c|}
\hline \multicolumn{2}{|l|}{ Keterangan } & $\begin{array}{l}\text { Standardized } \\
\text { Coefficients Beta } \\
\text { = nilai (p) }\end{array}$ & $\begin{array}{l}\text { Unstandardized } \\
\text { Coefficients B }\end{array}$ & $\begin{array}{c}\text { Unstandardized } \\
\text { Coefficients Std } \\
\text { Error }\end{array}$ \\
\hline Display ke loyalitas konsumen & \multirow{3}{*}{ P1 } &,- 052 &,- 034 &, 053 \\
\hline $\begin{array}{l}\text { Promosi penjualan keloyalitas } \\
\text { konsumen }\end{array}$ & & 228 & 234 &, 087 \\
\hline $\begin{array}{l}\text { Kualitas produkke loyalitas } \\
\text { konsumen }\end{array}$ & &, 553 & 320 &, 047 \\
\hline Display ke kepuasan pelanggan & \multirow{3}{*}{ P2 } &,- 110 &, 099 &, 094 \\
\hline $\begin{array}{l}\text { Promosi Penjualanke kepuasan } \\
\text { pelanggan }\end{array}$ & &, 075 & 108 & 156 \\
\hline $\begin{array}{l}\text { Kualitas Produkkekepuasan } \\
\text { pelanggan }\end{array}$ & & 261 & 213 &, 083 \\
\hline $\begin{array}{l}\text { Kepuasan Pelanggan ke loyalitas } \\
\text { konsumen }\end{array}$ & P3 & 0,278 & 0,197 & 0,053 \\
\hline
\end{tabular}

Tabel 4.4. Koefisien Jalur

\subsubsection{Perhitungan Pengaruh Tidak Langsung}

Untuk menghitung besarnya pengaruh tidak langsung dari variabel $\mathrm{X} 1, \mathrm{X} 2$, dan $\mathrm{X} 3$ terhadap $\mathrm{Z}$ dengan melewati $\mathrm{Y}$, peneliti harus menghitung terlebih dahulu besarnya pengaruh dari variabel $\mathrm{X} 1, \mathrm{X} 2$, dan $\mathrm{X} 3$ terhadap $\mathrm{Y}$ atau p21, p22, p23 x p3 dengan melihat Standardized Coefficients Beta dari nilai masing- masing p2 dan p3 sesuai yang ditampilkan pada Tabel 4.2. Berikut perhitungan pengaruh tidak langsung karena terdapat 3 variabel independen :

p2 $\times$ p3 $=-0,110 \times 0,278=-0,0306$ untuk X1 ke Y ke Z

p2 $\times$ p3 $=0,075 \times 0,0278=0,0209$ untuk X2 ke Y ke Z

p2 $\times$ p3 $=0,261 \times 0,278=0,073$ untuk X3 ke Y ke Z

\subsubsection{Perhitungan Total Pengaruh}

Setelah menghitung p21, p22, p23 x p3 dengan melihat Standardized Coefficients Beta,selanjutnya adalah menghitung total pengaruh (korelasi pengaruh langsung Display, Promosi Penjualan dan Kualitas Produk ke Loyalitas Konsumen) adalah sebagai berikut: $\mathrm{p} 1+(\mathrm{p} 2 \times \mathrm{p} 3)=-0,052+(-0,110 \times 0,278)=0,0826$ untuk X1 ke Z $\mathrm{p} 1+(\mathrm{p} 2 \times \mathrm{p} 3)=0,228+(0,075 \times 0,0278)=0,2489$ untuk $X 2 \mathrm{ke} \mathrm{Z}$ $\mathrm{p} 1+(\mathrm{p} 2 \times \mathrm{p} 3)=0,553+(0,261 \times 0,278)=0,6255$ untuk X3 ke Z

Pengaruh mediasi yang ditunjukkan oleh perkalian koefisien (p2 x p3) sebesar 0,0306, 0,0209, 0,073 dan untuk melihat signifikan atau tidak, diuji dengan Sobel Test sebagai berikut:

Dengan perhitungan standar error dari koefisien indirect effect $\left(\mathrm{Sp}^{2} p^{3}\right)$ berikut adalah rumus Sobel Test:

\section{a. Pengaruh display ke kepuasan pelanggan ke loyalitas konsumen}

$$
S p^{2} p^{3}=\sqrt{p 3^{2} S p^{2}+p 2^{2} S p 3^{2}+S p 2^{2} S p 3^{2}}
$$

\section{Keterangan :}

P2 dan P3 : koefisien dari Unstandardized Coeficients B pada tabel 4.4

Sp2 dan Sp3 : standar error dari Unstandardized Coeficients Standard Error pada tabel 4.4 Sehingga : 
$\mathrm{S} p^{2} p^{3}=\sqrt{(0,197)^{2}(0,094)^{2}+(0,099)^{2}(0,053)^{2}+(0,094)^{2}(0,053)^{2}}$

$\mathrm{Sp}^{2} p^{3}=\sqrt{0,0003949}=0,0198$

Berdasarkan hasil $\mathrm{Sp}^{2} p^{3}$ ini kita dapat menghitung nilai $\mathrm{t}$ statistik pengaruh intervening dengan rumus sebagai berikut:

$$
\mathrm{t}=\frac{p^{2} p^{3}}{\mathrm{~S} p^{2} p^{3}}=\frac{0,197 \times 0,099}{0,0198}=0,98
$$

oleh karena nilai t hitung lebih kecil dari t tabel dengan tingkat signifikan 0.05 yaitu sebesar 1,98, maka dapat disimpulkan bahwa koefisien intervening sebesar -0,0306 tidak signifikan yang berarti tidak ada pengaruh intervening.

\section{b. Pengaruh promosi penjualan ke kepuasan pelanggan ke loyalitas konsumen}

$$
s p^{2} p^{3}=\sqrt{p 3^{2} S p^{2}+p 2^{2} S p 3^{3}+S p 2^{2} S p 3^{2}}
$$

\section{Keterangan :}

P2 dan P3 : koefisien dari Unstandardized Coeficients B pada tabel 4.2

Sp2 dan Sp3 : standar error dari Unstandardized Coeficients Standard Error pada tabel 4.4

\section{Sehingga :}

$\mathrm{S} p^{2} p^{3}=\sqrt{(0,197)^{2}(0,156)^{2}+(0,108)^{2}(0,053)^{2}+(0,156)^{2}(0,053)^{2}}$

$\mathrm{Sp}^{2} p^{3}=\sqrt{0,001041}=0,0323$

Berdasarkan hasil $\mathrm{S}^{2} p^{3}$ ini kita dapat menghitung nilai $\mathrm{t}$ statistik pengaruh intervening dengan rumus sebagai berikut:

$$
\mathrm{t}=\frac{p^{2} p^{3}}{\mathrm{~S} p^{2} p^{3}}=\frac{0,197 \times 0,108}{0,0323}=0,6587
$$

oleh karena nilai t hitung lebih kecil dari t tabel dengan tingkat signifikan 0.05 yaitu sebesar 1,98, maka dapat disimpulkan bahwa koefisien intervening sebesar 0,0209 tidak signifikan yang berarti tidak ada pengaruh intervening.

\section{c. Pengaruh kualitas produk ke kepuasan pelanggan ke loyalitas konsumen}

$s p^{2} p^{3}=\sqrt{p 3^{2} S p^{2}+p 2^{2} S p 3^{3}+S p 2^{2} S p 3^{2}}$

$S p^{2} p^{3}=\sqrt{(0,197)^{2}(0,083)^{2}+(0,213)^{2}(0,053)^{2}+(0,083)^{2}(0,053)^{2}}$

$\mathrm{Sp}^{2} p^{3}=\sqrt{0,0004134}=0,0203$

Berdasarkan hasil $\mathrm{Sp}^{2} p^{3}$ ini kita dapat menghitung nilai t statistik pengaruh intervening dengan rumus sebagai berikut:

$$
\mathrm{t}=\frac{p^{2} p^{3}}{\mathrm{~S} p^{2} p^{3}}=\frac{0,197 \times 0,213}{0,0203}=2,067
$$

oleh karena nilai t hitung lebih besar dari t tabel dengan tingkat signifikan 0.05 yaitu sebesar 1,98, maka dapat disimpulkan bahwa koefisien intervening sebesar 0,073 signifikan yang berarti ada pengaruh intervening. 


\subsection{Pembahasan}

\section{Pengaruh Displayterhadap Loyalitas Konsumen}

Berdasarkan hasil yang diperoleh, didapatkan coefficients B sebesar -0,056 dan signifikan 0,325 dinyatakan tidak signifikan terhadap 0,00. Hal ini menjadikan tampilan/display toko online tidak berpengaruh positif dan signifikan terhadap loyalitas konsumen. Hal ini berbeda dengan Alharbi dan Alhider (2018) yang mengatakan bahwa desain website merupakan salah satu faktor yang penting. Begitu juga dengan penelitian yang dilakukan oleh Ujwala dan Vinay (2014) yang menyatakan betapa pentingnya fungsi customer service, namun pada penelitian ini tidak terlalu dilihat sebagai sesuatu yang krusial sehingga dalam penelitian ini display atau tampilan website pada toko online tidak terlalu penting atau tidak terlalu berpengaruh terhadap loyalitas konsumen dalam melakukan pembelian online di kota Bandung.

\section{Pengaruh Promosi Penjualan terhadap Loyalitas Konsumen}

Berdasarkan hasil yang diperoleh, didapatkan coefficients B sebesar 0,447 dan signifikan 0,000 dinyatakan signifikan terhadap 0,00 yang berarti bahwa promosi penjualan berpengaruh dan signifikan terhadap loyalitas konsumen yang berbelanja online di Kota Bandung. Hal ini sejalan dengan penelitian yang telah dilakukan oleh Daramola pada tahun 2014 yang menyatakan bahwa promosi penjualan memberikan pengaruh dan signifikan terhadap loyalitas konsumen (Daramola dkk, 2014). Dari tiga indikator yang digunakan kupon online mendapatkan respon yang kurang dan diskon harga online dirasakan lebih dapat meningkatkan loyalitas konsumen (Sinha dan Verma, 2015).

\section{Pengaruh Kualitas Produk Terhadap Loyalitas Konsumen}

Berdasarkan hasil yang diperoleh, didapatkan coefficients B sebesar 0,316 dan signifikan 0,000 dinyatakan signifikan terhadap 0,00. Hal ini berarti, kualitas produk memberikan pengaruh dan signifikan terhadap loyalitas konsumen dan ini sejalan dengan Penelitian yang telah dilakukan oleh Setiawan,dkk pada tahun 2016 . Namun konsumen merasa pada indikator produk bebas cacat dan kualitas bahan yang digunakan pada toko online masih dirasakan kurang. Hal ini tidak sesuai dengan penelitian yang dilakukan oleh Potdar dkk (2018), dimana produk yang baik dapat berdampak positif terhadap konsumen.

\section{Pengaruh Display, Promosi Penjualan dan Kualitas Produk pada Toko Online terhadap Loyalitas Konsumen Secara Simultan}

Berdasarkan hasil yang diperoleh, didapatkan coefficients B pada display toko online sebesar -0,053 dan signifikan 0,339 dinyatakan tidak signifikan terhadap 0,00 yang berarti bahwa secara simultan display, promosi penjualan dan kualitas produk pada toko online tidak berpengaruh dan tidak signifikan terhadap loyalitas konsumen. Hal ini sangat berbeda dengan hasil yang diperoleh oleh Khadka dan Maharjan (2017). Begitu juga pada promosi penjualan, coefficients B sebesar 0,256 dan signifikan 0,006 dinyatakan tidak signifikan terhadap 0,00 , sehingga kedua variabel ini tidak berpengaruh.

Pada penelitian ini display toko online dirasakan tidak memberikan pengaruh bagi konsumen karena tampilannya yang nyaris serupa dalam desain grafisnya, serta tingkat 
promosi yang dilakukan tidak mampu mempengaruhi loyalitas konsumen karena promosi yang ditawarkan juga nyaris serupa.

Berdasarkan hasil t hitung hanya display toko online yang tidak signifikan terhadap loyalitas konsumen yang berarti tidak berpengaruh, berbeda dengan yang dinyatakan oleh Mendez dkk (2015). Pada penelitian ini hanya pada kualitas produk dengan coefficients B sebesar 0,278 dan signifikan 0,000 dinyatakan signifikan terhadap 0,00 dan berpengaruh dengan t hitung 5,716 diatas t tabel 1,98. Sesuai dengan Alharbi dan Alhider (2018) pengembangan produk mampu meningkatkan loyalitas konsumen. Dirasakan konsumen cenderung terus bertahan pada toko online dengan kualitas produk yang baik dan konsisten.

\section{Pengaruh Display, Promosi Penjualan, Kualitas Produk Terhadap Loyalitas Konsumen Dengan Kepuasan Pelanggan Sebagai Variabel Intervening}

Perhitungan nilai p1 hubungan antara display, promosi penjualan dan kualitas produk terhadap loyalitas konsumen mengalami kenaikan setelah dihitung pengaruh $\mathrm{p}$ totalnya antara display, promosi penjualan dan kualitas produk terhadap loyalitas konsumen dengan kepuasan pelanggan. Namun setelah melakukan perhitungan dengan Path Analysis didapatkan nilai t hitung diatas t tabel pada pengaruh kualitas produk terhadap loyalitas konsumen sebesar 2,067 dimana hal ini berarti kepuasan pelanggan mampu meningkatkan loyalitas konsumen berdasarkan atas kualitas produk yang baik serta konsisten. Hal ini sesuai dengan penelitian yang dilakukan oleh Khadim dkk (2018) dan Alharbi \& Alhider (2018) dimana konsumen yang puas dengan pembelian yang dilakukan serta ragam produk yang dijual secara online mampu meningkatkan loyalitas konsumen. Pandey dan Chawla (2018) menyatakan niat pembelian dapat terbentuk dari kesan yang baik saat melakukan pembelian sebelumnya.

\section{SIMPULAN DAN SARAN}

\subsection{Simpulan}

Berdasarkan hasil perhitungan yang di dapatkan di atas dapat disimpulkan bahwa:

1. Secara parsial Display toko online tidak berpengaruh pada loyalitas konsumen karena dirasakan tidak ada perbedaan fitur dan desain grafis antara satu toko online yang satu dengan lainnya. Sedangkan pada variabel promosi penjualan memiliki pengaruh dan signifikan terhadap loyalitas konsumen, hal ini dikarenakan keberadaannya dirasakan tidak memberi banyak pengaruh bagi konsumen . untuk hal kualitas produk pada toko online memiliki pengaruh dan signifikan terhadap loyalitas konsumen.

2. Secara simultan, display, promosi penjualan dan kualitas produk pada toko online tidak berpengaruh dan tidak signifikan

3. Secara simultan dengan menggunakan variabel kepuasan pelanggan sebagai intervening, mendapatkan hasil bahwa variabel display toko online tidak memberikan perubahan pengaruhnya pada loyalitas konsumen. Selain itu, promosi penjualan tidak berpengaruh dan signifikan terhadap loyalitas konsumen dengan kepuasan pelanggan sebagai intervening, ini karena ketika suatu toko online memberikan promosi hanya berpengaruh sesaat ketika terjadi promosi saja, sehingga setelah dimasukkan variabel 
intervening kepuasan pelanggan tidak didapatkan dampak yang mempengaruhi loyalitas konsumen. Kepuasaan pelanggan yang bersifat sementara tidak mampu mempengaruhi loyalitas konsumen. Yang ketiga, setelah ditambahkan variabel intervening kepuasan konsumen kualitas produk dapat memberikan pengaruh terhadap loyalitas konsumen. Hal ini dikarenakan kepuasan pelanggan pada kualitas produk yang baik dan konsisten dalam mempertahankan produknya dapat meningkatkan loyalitas konsumen.

\subsection{Saran}

Demi meningkatkan dan menjaga loyalitas pada konsumen terdapat beberapa saran yang dapat dilakukan oleh pengusaha toko online yaitu :

1. Dalam hal tampilan display pada toko online Para produsen toko online agar dapat lebih mengembangkan fitur dan desain website guna menarik, mempermudah konsumen saat berbelanja dan menjadikan website tersebut berbeda dengan website atau toko online lainnya sehingga konsumen tidak bosan atau jenuh ketika berbelanja di website tersebut.

2. Promosi penjualan harus lebih ditingkatkan dengan tidak hanya promosi pada website yang dimiliki namun melalui media lainnya. Sehingga konsumen mengetahui mengenai promosi tersebut. Jenjang antara periode promosi juga harus diperhatikan sehingga konsumen akan terus bertahan untuk melakukan pembelian.

3. Kualitas produk yang sudah baik harus lebih ditingkatkan dan terus dipertahankanseperti menghindari pengiriman produk cacat, kesalahan model, ukuran atau warna, dsb karena akan mengurangi kepuasan pelanggan yang berdampak pada loyalitas konsumen. 


\section{DAFTAR PUSTAKA}

Abdeldayem, M. M. (2016). A study of customer satisfaction with online shopping: evidence from the UAE. International Journal of Advanced Media and Communication. https://www.researchgate.net/publication/220610482.

Agensi pemasaran media social We Are Social (www.HootSuite.com). Diakses Pada Tanggal 15 September 2019.

Agustine, J., dan Koeshartono, D. (2014). Pengaruh Karakteristik Website Terhadap Kepuasan dan Dampaknya Pada Kepercayaan Konsumen. Program Studi Manajemen, Fakultas Ekonomi.

Alharbi, A. H., \& Alhider, I. H. (2018). The Impact of Customer Satisfaction and Loyalty on E-Marketing: Moderating Effect of Perceived Value. Journal of Marketing and Customer Research. Vol. 46, 70-77.

Al-Jahwari, N. S., Khan, M. F. R., Al-Kalbani, G. K., \& Khansouri, S.S. (2018). Factor Influencing Customer Satisfaction of Online Shopping In Oman - Youth Perspective. Humanities and Social Science Reviews, 6(2), 64-73.

Burinskiene, A., Daskevic, D., dan Gediminas, V. (2014). Consumer Demand: Online or Retail Store. Journal Economics and Management. Vol 19(2), ISSN 2029 - 9338 (ONLINE), page: 172-187.

Caner, D. \& Banu, D. (2015). Key Factors of Online Customer Satisfaction. International Journal of Academic Research in Business and Social Sciences. Vol. 5, pp. 97-111.

Chi, S. C., Jiun, W. C., \& Lin, Y. (2015). Female Online Shoppers: Examining the Mediating Roles of E-Satisfaction and E-Trust on E-Loyalty Development. Internet Research/Emerald Insight. Vol. 25, pp.-

Daramola, G.C., Okafor, L.I., \& Bello, M.A. (2014). Sales promotion on purchasing behavior. International Journal of Business and Marketing Management, 2(1), 8-13.

Farah, G. A., Ahmad, M., Muqarrab, H., Turi, J. A., \& Bashir, S. (2018). Online Shopping Behavior among University Students: Case Study of Must University. Advances in Social Sciences Research Journal, 5(4) 228-242.

Grant, A. E., \& Meadows, J. H. (2008). Communication Technology Update and Fundamentals (11th Edition). Taylor \& Francis.

Gozali, I. (2009). Aplikasi Analisis Multivariate dengan SPSS. Semarang: Badan Penerbit Universitas Diponegoro.

Harahap, D. A., \& Amanah, D. (2018). Perilaku Belanja Online di Indonesia: Studi Kasus. Jurnal Riset Manajemen Sains Indonesia (JRMSI). Vol 9, No. 2, e-ISSN: 2301-8313, hal: 193-213.

Hatta, I. H., Rachbini, W. \& Derriawan. (2018). Brand Image Analysis, Promotion, Satisfaction and Customer Loyalty. IOSR Journal of Business and Management, Vol. 20, Issue. 12, pp 50-55.

Himawan, L., \& Abduh, D. (2013). Analysis of Online Sales Promotion toward Youth Purchase Intention in Indonesia (Case Study of Apparel Industry). Research Journal of Management Sciences, vol. 13, pp. 4677-4690. 
Huang, A. H., Chen, K., Yen, D. C., \& Tran, T. P. (2015). A Study of Factors That Contribute To Online Review Helpfulness. Computers in Human Behavior, 48, 17-27.

Jain, N. K., Kamboj, S., Kumar, V., \& Rahman, Z. (2018). Examining consumer-brand relationships on social media platforms. Marketing Intelligence \& Planning, 36(1), 63-78.

Katawetawaraks, C., \& Wang, C. L. (2011). Online Shopper Behavior: Influences of Online Shopping Decision. Asian Journal of Business Research, 1 (2), 66-74.

Khadim, R. A., Hanan, M. A., Arshad, A., Saleem, N., \& Khadim, N. A. (2018). Revisiting Antecedents of Brand Loyalty: Impact of Perceived Social Media Communication with Brand Trust and Brand Equity as Mediators. Academy of Strategic Management Journal, 17(1), 1-13.

Khadka, K. \& Maharja, S. (2017). Customer Satisfaction and Customer Loyalty. Centria University of Applied Sciencist Business Management. P. 58-64

Kumar C., Mosharraf, H., Farhad, H., \& Jakirul, I. (2013). Analyzing the Effect of Sales Promotion and Advertising on Consumer's Purchase Behavior. Word Journal of Social Science, 3(4), 183-194.

Lee, E. J, \& Shin, S. Y. (2014). When Do Consumers Buy Online Product Reviews: Effects of Review Quality, Product Type, and Reviewer's Photo. Computers in Human Behavior, 31, 356-366.

Lestari, A., \& Yulianto, E. (2018). Pengaruh Kualitas Produk Terhadap Loyalitas Pelanggan Dengan Kepuasan Pelanggan Sebagai Variabel Mediasi. Jurnal Administrasi Bisnis (JAB). Vol. 54, No.1.

Ludin, I. H., \& Cheng, B. L. (2014). Factors Influencing Customer Satisfaction and ELoyalty: Online Shopping Environment among the Young Adults. Management Dynamics in the Knowledge Economy. Vol. 2, pp. 462-471.

Masoud, E.Y. (2013). The Effect of Perceived Risk on Online Shopping in Jordan. European Journal of Business and Management www.iiste.org ISSN 2222-1905 (Paper) ISSN 2222-2839 (Online) Vol.5, No.6.

Mendez, M., Bendixen, M., Abratt, R., Yurova, Y., \& O’Leary, B. (2015). Sales promotion and brand loyalty: Some new insights. International Journal of Education and Social Science, 2(1), 103-117.

Momotaz, S. N., \& Hasan, M. S. (2018). Exploring the Impact of Service Quality Factors on Customer Satisfaction towards Online Shopping: Evidence from Bangladesh. World, 8(1), 102-123.

Neha, S. \& Manoj, V. (2013). Impact of Sales Promotion Tools on Consumer"s Purchase Decision towards White Good (Refrigerator) at Durg and Bhilai Region of CG, India. Research Journal of Management Sciences. Vol. 2(7), pp. 10-14.

Negadeepa, C., Tamil, S., \& Pushpa, A. (2015). Impact of Sale Promotion Techniques on Consumers' Impulse Buyıng Behaviour towards Apparels at Bangalore. Asian Journal of Management Sciences \& Education, 4(1), 116-122.

Pandey, S., \& Chawla, D. (2018). Online Customer Experience (OCE) in Clothing ERetail: Exploring OCE Dimensions and Their Impact on Satisfaction and Loyalty- 
Does Gender Matter?. International Journal of Retail \& Distribution Management, 46(3), 323-346.

Peng, H., and Tao, S. (2018). A Research on the Influential Factors of Listing Sales Based on Online Information in Short Rental Markets. Wuhan International Conference on eBusiness. p. 484 - 489.

Potdar, V., Joshi, S., Harish, R., Baskerville, R., \& Wongthongtham, P. (2018). A Process Model For Identifying Online Customer Engagement Patterns On Facebook Brand Pages. Information Technology \& People, 31(2), 595-614.

Rahadi, D.R., (2013), Pengaruh Karateristik Website Terhadap Kepuasan Pelanggan, Jurnal Manajemen dan Binis, Vol. 5, No. 7.

Richard, L., \& Zhang, H. (2014). Sales Promotion and Purchasing Intention: Applying Technology Acceptance Model in Consumer-To-Consumer Marketplaces. International Journal of Business, Humanities and Technology, 4(3), 1-5.

Setiawan, H., Minarsih, M. M., dan Fathoni, A. (2016). Pengaruh Kualitas Produk, Kualitas Pelayanan dan Kepercayaan Terhadap Kepuasan Nasabah dan Loyalitas Nasabah Dengan Kepuasan Sebagai Variabel Intervening ( Studi Kasus Pada Nasabah Koperasi Rejo Agung Sukses Cabang Ngaliyan ).Journal Of Management, 2(2).

Shariari, S., Shahriari, M., \& Gheiji, S. (2015). ECommerce and It Impacts on Global Trend and Market. International Journal of Research - Granthaalayah. Vol. 3, pp. 4955.

Shamout, M. D. (2016). The Impact of Promotional Tools on Consumer Buying Behavior in Retail Market. International Journal of Business and Social Science, vol. 7, pp. 7585

Sinha, S. K., \& Verma, P. (2015). A Study of non-monetary sales promotion and reward. International Journal of Commerce, Business and Management, 4(2), 1136-1139.

Tjahjaningsih, E. (2013). Pengaruh Citra dan Promosi terhadap Kepuasan Pelanggan serta dampaknya terhadap Loyalitas Pelanggan (Studi Pada Pelanggan Supermarket Carrefour di Semarang). Jurnal Fakultas Ekonomi Universitas Stikukbank.

Ujwala D. \& Vinay K. (2014). A study of factors affecting online buying behavior: a conceptual model.

Winnie, P. M. W. (2014). The Effects of Website Quality on Customer eLoyalty: The Mediating Effect of Trustworthiness. International Journal of Academic Research in Business and Social Sciences. Vol. 4, pp. 19-4.

$\mathrm{Wu}$, I. L. (2013). The antecedents of customer satisfaction and its link to complaint intentions in online shopping: An integration of justice, technology, and trust.International Journal of Information Management, 33(1), 166-176.

Yoebrilianti, A. (2018). Pengaruh Promosi penjualan Terhadap Minat Beli produk Fashion Dengan Gaya Hidup Sebagai Variabel Moderator (Survei Konsumen Pada Jejaring Sosial). Program Studi Manajemen Fakultas Ekonomi dan Bisnis. Jurnal Manajemen, $8(1), 20-4$.

Zikmund, W.G., Babin, B.J., Carr, J.C., \& Griffin, M. (2010). Business Research Methods, $8^{\text {th }}$ edition. South Western: Cengage Learning. 